\title{
Inhibition of Paracetamol-Induced Acute Kidney Damage in Rats Using a Combination of Resveratrol and Quercetin
}

\author{
Inhibición de Daño Renal Agudo Inducido por Paracetamol en \\ Ratas Usando una Combinación de Resveratrol y Quercetina
}

\author{
Mohamed A. Haidara ${ }^{1,2}$; Fahaid Al-Hashem ${ }^{1}$; Abbas O. El Karib ${ }^{1}$; Mohamed S. Zaki ${ }^{3,4}$; \\ Samaa S. Kamar ${ }^{5}$; Mahmoud H. El-Bidawy ${ }^{2,6}$ \& Bahjat Al-Ani ${ }^{1}$
}

HAIDARA, M. A.; AL-HASHEM, F.; EL KARIB, A. O.; ZAKI, M. S.; KAMAR, S. S.; EL-BIDAWY, M. H. \& AL-ANI, B. Inhibition of paracetamol-induced acute kidney damage in rats using a combination of resveratrol and quercetin. Int. J. Morphol., 37(4):1422-1428, 2019.

SUMMARY: Paracetamol (also called acetaminophen, or APAP) overdose causes acute damage to the liver and kidneys in both humans and experimental animal models via the induction of the oxidative stress pathway. We sought to determine whether the combined antioxidants and anti-inflammatory compounds, resveratrol (RES) and quercetin (QUR) can protect against kidney injury induced by a toxic dose of APAP in a rat model of APAP-induced acute kidney injury. Rats were either received a single dose of APAP (2 g/kg) before being sacrificed after 24 hours or were pre-treated for 7 days with combined doses of RES (30 mg/kg) and QUR (50 mg/kg) before being given a single dose of APAP and then sacrificed 24 hours post APAP ingestion. Harvested kidney tissues were prepared for light microscopy staining, and tissue samples were assayed for (i) biomarkers of oxidative stress and antioxidant, malondialdehyde (MDA) and superoxide dismutase (SOD); and (ii) biomarkers of inflammation, tumor necrosis factor-alpha (TNF- $\alpha$ ) and interleukin-6 (IL-6). Hematoxylin and eosin (H\&E) stained images showed that APAP overdose induced acute kidney injury as demonstrated by widening of glomeruli space (Bowman space), tubular dilatation, numerous cellular debris in the renal tubules with tubular epithelial degeneration, and vacuolization, which were effectively protected by RES+QUR except a partial protection of the glomeruli space was observed. In addition, APAP significantly $(\mathrm{p}<0.05)$ modulated tissue levels of MDA, SOD, TNF- $\alpha$, and IL-6, which were protected by RES+QUR. Furthermore, a significant $(\mathrm{p}<0.0001)$ positive correlation was observed between glomeruli space and TNF- $\alpha,(r=0.8899)$, IL-6 ( $r=0.8986)$, and MDA $(\mathrm{r}=0.8552)$, whereas glomeruli space scoring versus SOD showed negative correlation $(\mathrm{r}=-0.7870)$. We conclude that resveratrol plus quercetin substantially protects against APAP-induced acute kidney injury in rats, possibly via the augmentation of antioxidants and inhibition of oxidative stress and inflammation.

KEY WORDS: Acute kidney injury; Paracetamol; Resveratrol; Quercetin; Rat model.

\section{INTRODUCTION}

Paracetamol (APAP) induced combined hepatonephrotoxicity is common in both humans and experimental animal models after accidental or intentional ingestion of an overdose of the drug (McGill et al., 2012; Karaali et al., 2018). About $50 \%$ of acute liver failure admitted cases in the United States of America are caused by APAP poisoning (Ostapowicz et al., 2002; Larson et al., 2005). It is the most common agent of intentional self-harm and APAP poisoning claimed the life of 284 persons aged 12 years and over between 1993-1996 in England and Wales, UK (Hawton et al., 2004). APAP is metabolised in the liver and hepatotoxic metabolites that represents about $10 \%$ of the whole metabolites are rapidly inactivated by glutathione (GSH) to protect the hepatocytes (James et al., 2003). But, with the drug overdose for example, the elevated levels of liver toxic metabolites, mainly N-acetyl-p-benzoquinoimine (NAPQI) rapidly deplete GSH and covalently modify cellular proteins leading to the generation of high levels of reactive oxygen species (ROS) and depletion of the ATP, which results in mitochondrial damage and hepatocyte and kidney injuries

\footnotetext{
${ }^{1}$ Department of Physiology, College of Medicine, King Khalid University, Abha 61421, Saudi Arabia.

${ }^{2}$ Department of Pysiology, Kasr Al-Aini Faculty of Medicine, Cairo University, Egypt.

${ }^{3}$ Department of Anatomy, College of Medicine, King Khalid University, Abha 61421, Saudi Arabia.

${ }^{4}$ Department of Histology, Faculty of Medicine, Zagazig University, Zagazig, Egypt.

${ }^{5}$ Department of Medical Histology, Kasr Al-Aini Faculty of Medicine, Cairo University, Egypt.

${ }^{6}$ Department of BMS, Division of Physiology, College of Medicine, Prince Sattam Ibin Abdulaziz University, Al-Kharj, Saudi Arabia.

FUNDING. This work was supported by the Research Deanship of King Khalid University, Grant/Award Number: KKU-Project No. R.G.P.1/88/40.
} 
HAIDARA, M. A.; AL-HASHEM, F.; EL KARIB, A. O.; ZAKI, M. S.; KAMAR, S. S.; EL-BIDAWY, M. H. \& AL-ANI, B. Inhibition of paracetamol-induced acute kidney damage in rats using a combination of resveratrol and quercetin. Int. J. Morphol., 37(4):1422-1428, 2019.

(Hinson et al., 2004). However, it was postulated that depletion of $90 \%$ of GSH in hepatocytes is critically necessary for the development of cell necrosis (Henderson et al., 2000). In addition, hepatic inflammatory cytokines are also reported to be involved in APAP-induced liver injury (Blazka et al., 1996).

Quercetin and resveratrol are polyphenolic antioxidants found in fruits, vegetables, and grains (Burda \& Oleszek, 2001; Cudmore et al., 2012). They have been widely known to have potent cardiovascular protective and therapeutic effect via scavenging ROS (Hung et al., 2000), anti-inflammatory effects (Rogerio et al., 2007; Al-Ani, 2013), inhibit lipid peroxidation (Frankel et al., 1993), and liver and kidney protection (Faghihzadeh et al., 2015; Zhang et al., 2017). The combination of resveratrol and quercetin has not been used before to study the protection of kidney tissue upon paracetamol intoxication in an animal model. Therefore, this study was designed to investigate the degree of protection by resveratrol and quercetin given in combination against APAP intoxication to the glomerular and renal tubular structure, and compare it with the level of protection provided by these agents to known kidney injury biomarkers.

\section{MATERIAL AND METHOD}

Reagents and assay kits. Quercetin (C15H10O7, CAS Number 117-39-5) was purchased from Sigma-Aldrich (St. Louis, MO, USA) and was prepared daily and freshly by dissolving in a normal saline solution $(0.9 \% \mathrm{NaCl})$ to the final concentration of $50 \mathrm{mg} / \mathrm{ml}$. Resveratrol (C14H12O3, Cat No. R5010) was also purchased from Sigma-Aldrich (St. Louis, MO, USA) and was prepared daily and freshly by dissolving in a saline solution $(0.9 \% \mathrm{NaCl})$ containg 20 $\%$ hydroxypropyl cyclodextrin (American Maize-Products Co., Hammond, IN, USA) to a final concentration of $30 \mathrm{mg} /$ $\mathrm{kg}$. Assay kits for determination of malondialdehyde (MDA, Cat No. NWK-MDA01) were purchased from NWLSS (Vancouver, BC, Canada). Superoxide dismutase (SOD) assay kit was purchased from Cayman Chemical, Cat. No.706002. ELISA kits for determination the levels of IL-6 (Cat No. ELR-IL6-001) was purchased from RayBio, GA, USA. ELISA kits for determination of TNF- $\alpha$ (Cat No. ab46070) was purchased from Abcam, Cambridge, UK.

Animals. All experimental procedures were approved by the medical research ethical committee at King Khalid University and according to the Guide for the Care and Use of Laboratory Animals published by the US National Institutes of Health (NIH publication No.85-23, revised 1996). Sprague Dawley rats $(n=18)$ weighing 170-
$200 \mathrm{~g}$ were used in this study. All rats were bred and housed in the research center of King Khalid University, College of Medicine (Abha, Saudi Arabia), at temperature of $23 \pm 1$ ${ }^{\circ} \mathrm{C}$ and a $12 \mathrm{~h}$ light: $12 \mathrm{~h}$ dark cycle. Rats had free access to tap water and fed standard laboratory chow during the acclimatization period.

Experimental design. After a one week adaptation period, rats were randomly assigned into 3 groups $(n=6$; each) and were distributed in their corresponding cages and classified as follows: (1) Control group: rats received normal saline daily for 7 days; (2) APAP intoxicated group (Model group): rats received normal saline for 7 consecutive days and then given a single dose of APAP (2 g/kg, orally); and (3) RES+QUR+APAP group: rats were pre-treated with RES (30 mg/kg) and $50 \mathrm{mg} / \mathrm{kg}$ QUR for 7 consecutive days and then administered with a single dose of $\operatorname{APAP}(2 \mathrm{~g} / \mathrm{kg}$, orally). APAP was administered to the desired groups one hour after the last dose of treatment on day 7 and all treatment in all groups were administered i.p. in a final volume of $1 \mathrm{ml}$. All animals were sacrificed at day 8 .

Determination of tissue levels of MDA, SOD, and TNF$\boldsymbol{\alpha}$, and IL-6. At day 8, animals were sacrificed and tissue levels of MDA, SOD, TNF- $\alpha$, and IL- 6 were determined using ELISA kits according to the manufacturer's instructions.

Histological examination. As we previously reported (AlHashem et al., 2019), kidney specimens were immediately fixed in $10 \%$ formal saline for 24 hours. Paraffin blocks were prepared,and $5 \mu \mathrm{m}$ thick sections were subjected to hematoxylin and eosin $(\mathrm{H} \& \mathrm{E})$ stain to elucidate the status of kidney architecture and the structural changes.

Statistical and morphometric analysis. The data were expressed as mean \pm standard deviation (SD). Data were processed and analyzed using the SPSS version 10.0 (SPSS, Inc., Chicago, Ill., USA). One-way ANOVA was done followed by Tukey's post hoc test. Pearson correlation statistical analysis was done for detection of a probable significance between two different parameters. Results were considered significant if $\mathrm{p} \leq 0.05$.

Using "Leica Qwin 500 C" image analyzer (Cambridge, UK), the diameters of glomeruli space were obtained in 10 non overlapping high power fields/ rat of H\&E-stained sections. Quantitative data were tabulated as means and standard deviations (SD) and compared using analysis of variance (ANOVA) followed by post-Hoc analysis (Tukey test). Significant difference was considered when P-value $<0.05$. Calculations were made on SPSS software (version 19). 


\section{RESULTS}

Resveratrol plus quercetin protect kidney tissue against APAP-induced injury. Acute kidney injury was induced in the model group of rats by a toxic dose ( $2 \mathrm{~g} / \mathrm{kg}$ body weight) of APAP. Harvested kidney tissues from all animal groups at day 8 were stained with $\mathrm{H} \& \mathrm{E}$ and examined under light microscopy. Compared to normal tissue histological structure of renal corpuscles or Malpighian renal corpuscles (MC), proximal (P) and distal (D) convoluted tubules in the control group (Figs. 1A and 1B), APAP substantially damaged the kidney tissue as demonstrated by widening of glomeruli space (arrowhead), tubular dilatation (curved arrow), numerous cellular debris in the renal tubules with tubular epithelial degeneration, vacuolization (wavy arrows), and prominent desquamation of the lining epithelium (Figs. 1C and 1D). Pretreatment with resveratrol plus quercetin preserved normal structure of renal corpuscles and convoluted tubules (Figs. 1E and $1 \mathrm{~F})$. However, few mildly dilated glomeruli space were noted in some fields. Furthermore, quantitative analysis of the mean diameter of glomeruli space revealed substantial protection $(\mathrm{p}<0.0001)$ by resveratrol plus quercetin but still significant $(\mathrm{p}=0.0012)$ to the control group (Fig. 1G).

Resveratrol plus quercetin protect the modulation of biomarkers of kidney tissue injury induced by APAP. High blood and tissue levels of inflammation and oxidative stress are known to be involved in the pathology of acute kidney injury in animal models and humans (Askari et al., 2018; Ravarotto et al., 2018). To investigate the level of inhibition of modulation of these biomarkers by combined injections of resveratrol and quercetin for 7 days prior to APAP intoxication; we measured tissue levels of inflammation (Figs. 2A and 2B) and oxidative stress and antioxidant (Figs. $3 \mathrm{~A}$ and $3 \mathrm{~B}$ ) in all rat groups. As shown in Figures $2 \mathrm{~A}$ and $2 \mathrm{~B}$, acute kidney injury induced by APAP significantly $(\mathrm{p}<0.05)$ increased TNF- $\alpha$ and IL-6, which were substantially protected by RES+QUR. In addition, APAP significantly $(\mathrm{p}<0.05)$ augmented the oxidative stress biomarker MDA (Fig. 3A) and ameliorated the antioxidant SOD (Fig. 3B), which were also substantially protected by RES+QUR.

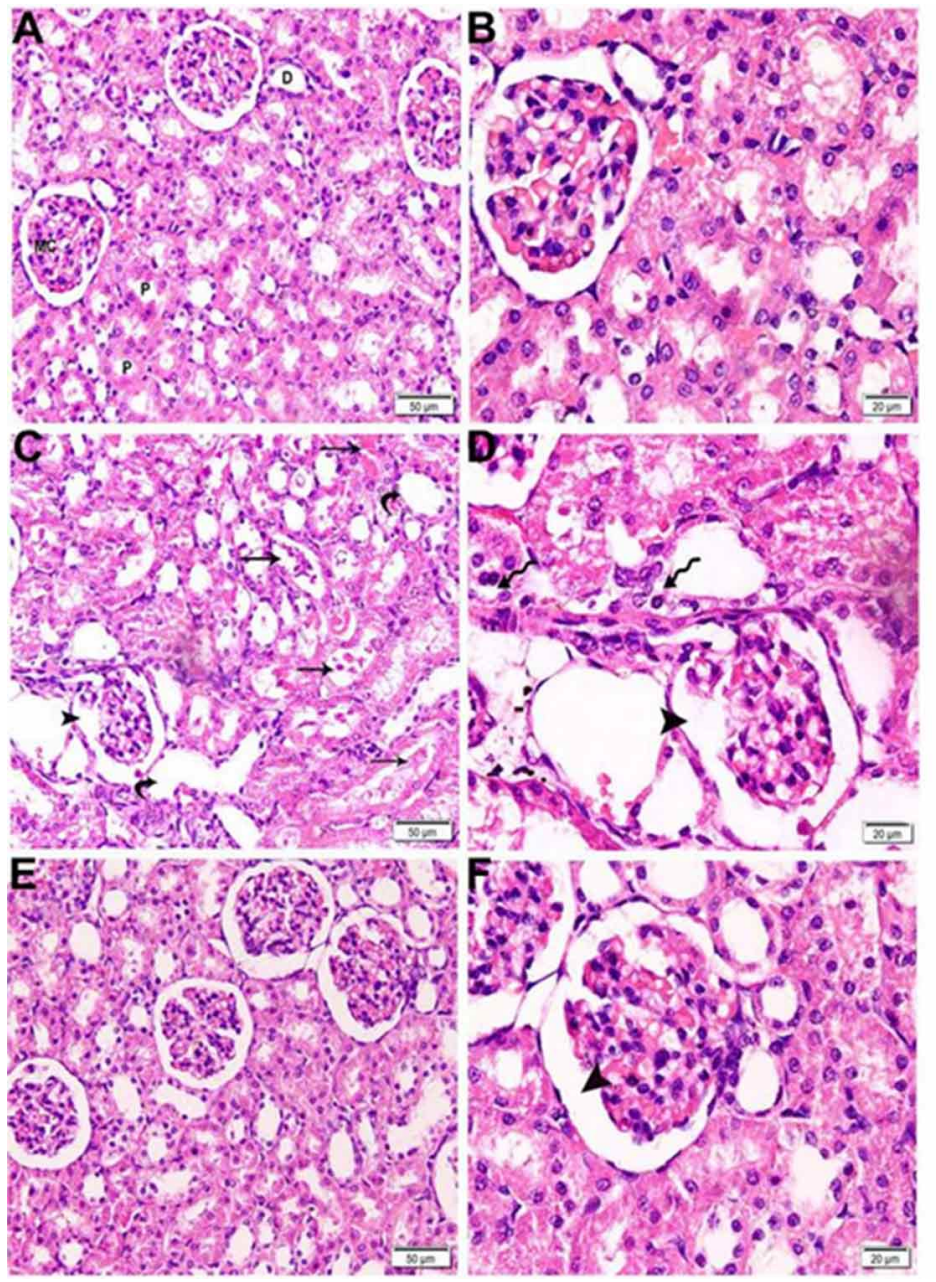

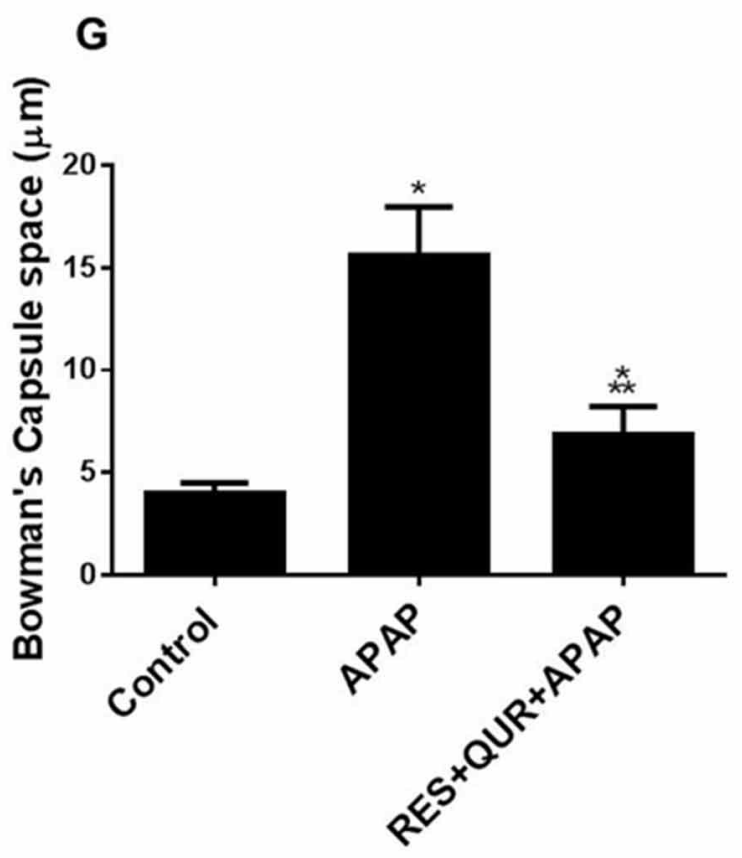

Fig. 1. Resveratrol and quercetin protect against APAPinduced acute kidney injury in rats. H\&E stained kidney sections (A, C, E x200; B, D, F x 400) obtained at the end of the experiment in different groups of rats used in this study; Control group (A and B), APAP group (C and D), and RES+QUR+APAP group (E and F). Quantitative analysis of the mean diameter of Glomeruli's space is shown in (G). Abbreviations: MC, renal corpuscles or Malpighian renal corpuscles; $\mathrm{P}$, proximal convoluted tubule; D, distal convoluted tubule. 
A

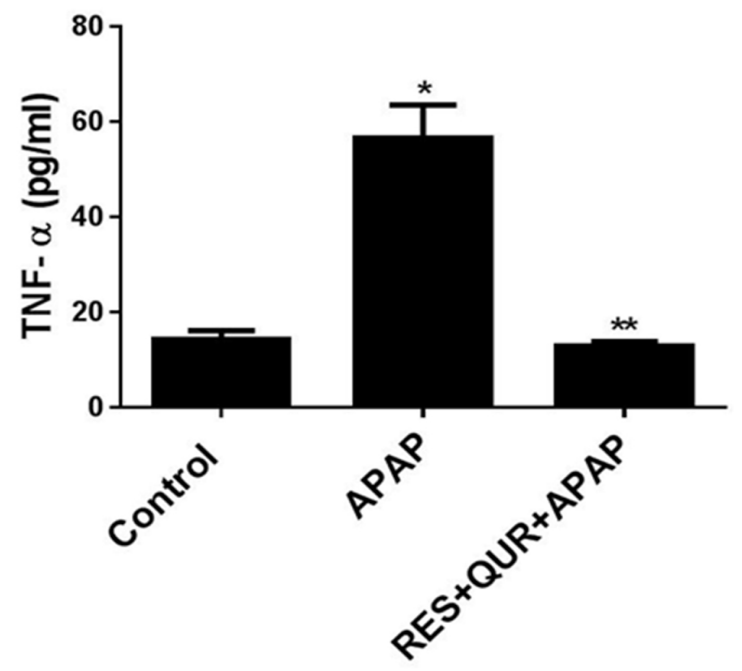

B

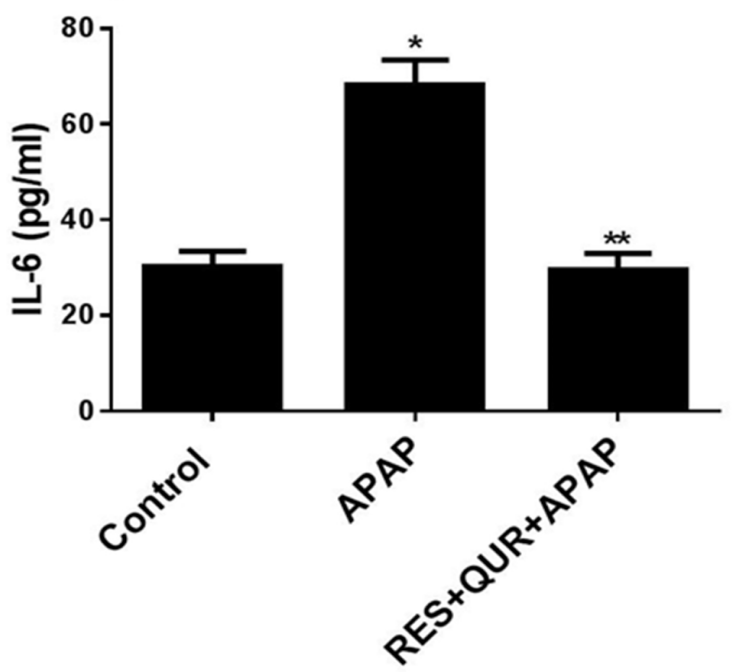

Fig. 2. Resveratrol and quercetin inhibit APAP-induced inflammatory biomarkers in rats. Kidney homogenates levels of TNF-a (A) and IL-6 (B) were measured at the end of the experiment in different groups of rats used in this study; Control group, APAP group, and RES+QUR+APAP group. Results represent the mean $( \pm \mathrm{SD}) ; \mathrm{n}=6$ for each group. Experiments were performed in triplicate. $* \mathrm{p}<0.05$ versus control, $* * \mathrm{p}<0.05$ versus APAP.

A

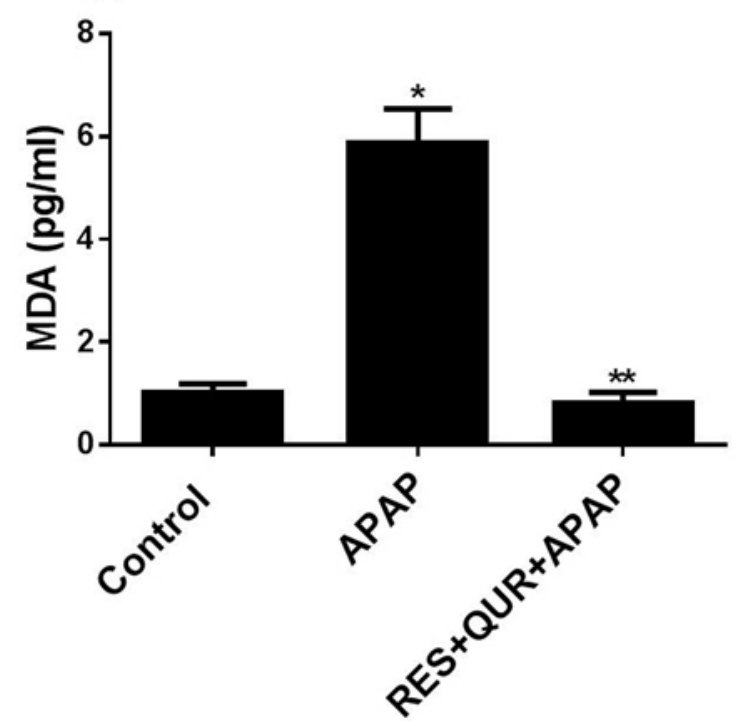

B

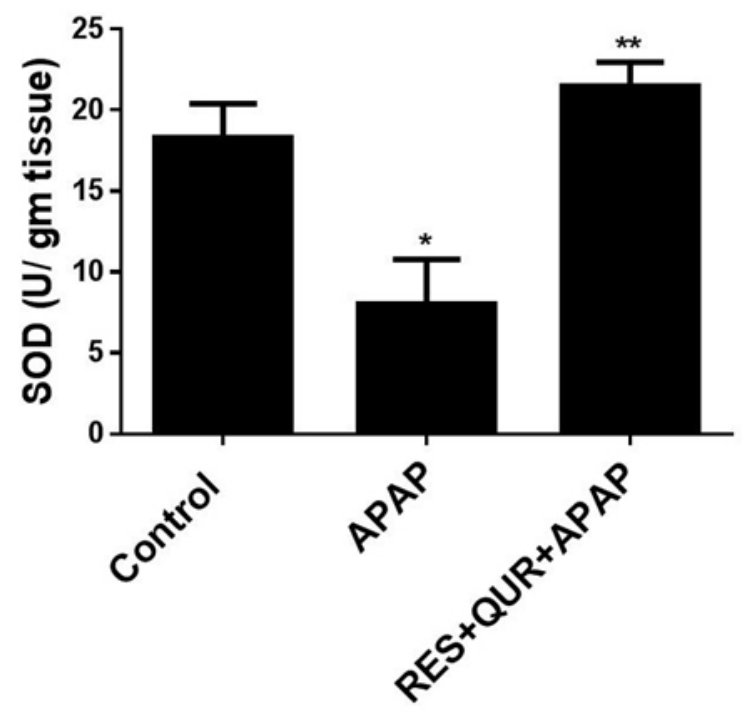

Fig. 3. Resveratrol and quercetin protect against APAP-induced modulation of oxidative stress and antioxidant biomarkers in rats. Kidney homogenates levels of MDA (A) and SOD (B) were measured at the end of the experiment in different groups of rats used in this study; Control group, APAP group, and RES+QUR+APAP group. Results represent the mean $( \pm \mathrm{SD}) ; \mathrm{n}=6$ for each group. Experiments were performed in triplicate. $* \mathrm{p}<0.05$ versus control, $* * \mathrm{p}<0.05$ versus APAP.

Positive correlation between renal corpuscle injury scoring and biomarkers of inflammation and oxidative stress. We determined the correlation between the mean diameter of glomeruli capsule space and the tissue levels of inflammation and oxidative stress biomarkers in all animal groups in order to further confirm and characterize that the role of the antioxidants and anti-inflammatory agents, resveratrol plus quercetin are stable and useful "drugs" in kidney injury rats, and to further support the link between acute kidney injury and inflammation and oxidative stress. As shown in Figures 4A-C, a positive correlation was shown between acute kidney injury and these biomarkers; glomeruli space versus TNF- $\alpha$ $(r=0.8899)(p<0.0001)$, glomeruli space versus IL-6 
$(\mathrm{r}=0.8986)(\mathrm{p}<0.0001)$, and glomeruli space versus MDA $(\mathrm{r}=0.8552)(\mathrm{p}<0.0001)$. In addition, a negative correlation

A

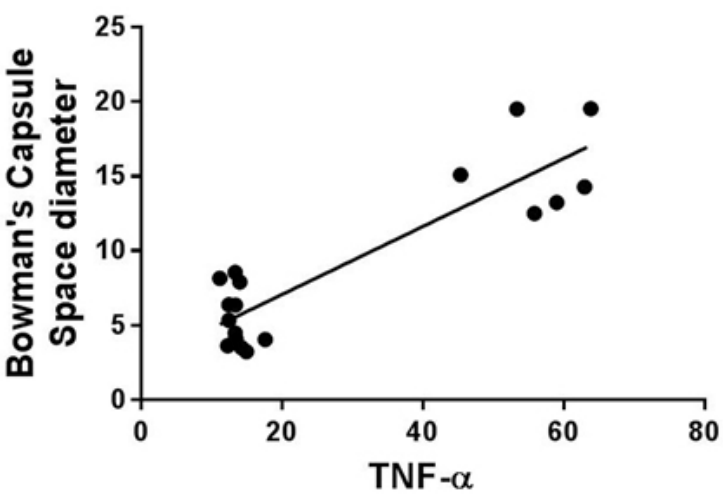

C

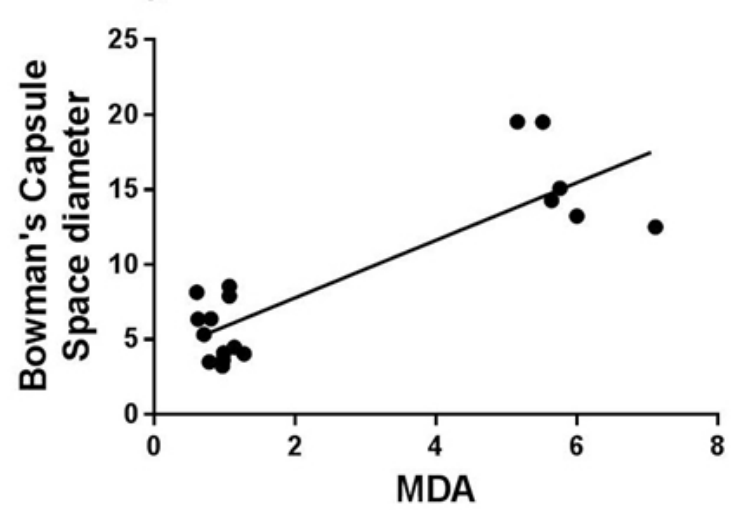

was shown between glomeruli space and the antioxidant SOD $(r=-0.7870)(p<0.0001)($ Fig. 4D).
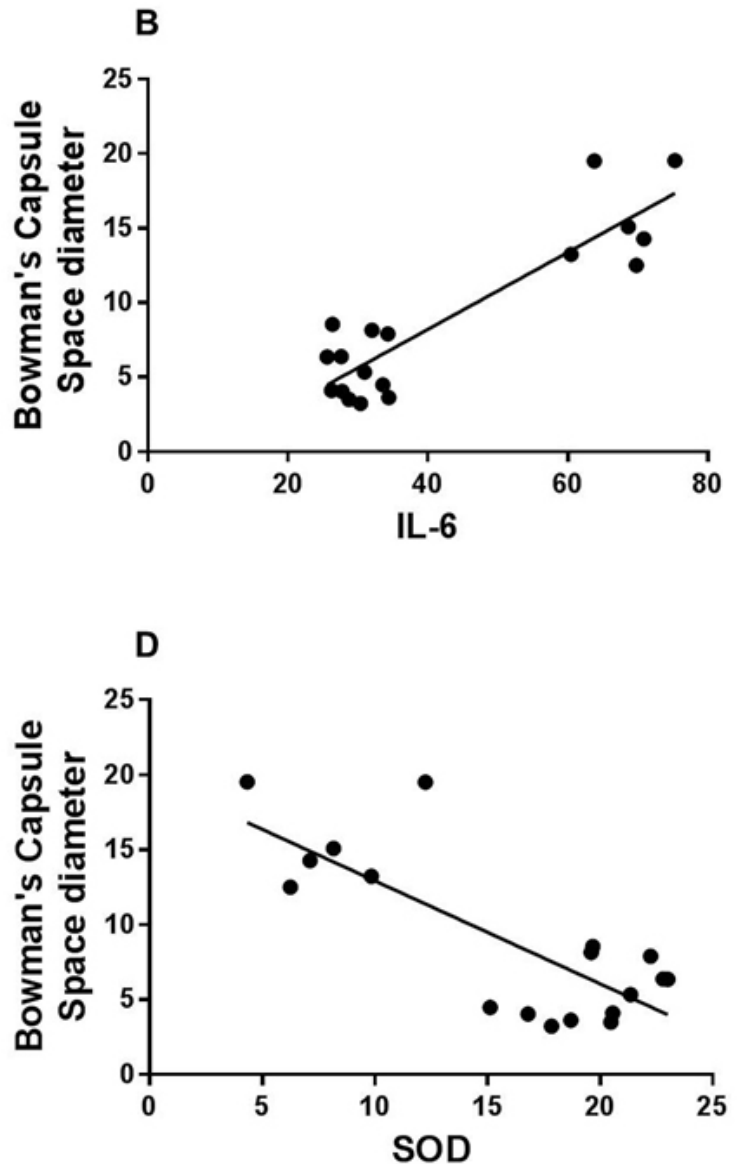

Fig. 4. Correlation between Glomeruli's space and biomarkers of inflammation, oxidative stress, and antioxidant. The mean diameter of Glomeruli's space was measured in all groups of rats on day 8 and the relationship between Glomeruli's space and TNF- $\alpha$, IL-6, MDA, and SOD are shown in (A - D), respectively.

\section{DISCUSSION}

The main objective of our study was to investigate the potential protective effect of the combined two antioxidants, resveratrol and quercetin on kidney damage induced by APAP in a rat model of acute kidney injury using light microscopy. In addition, our protective approach using both agents was also used to assess levels of kidney injury biomarkers, oxidative stress, antioxidant, and inflammation using ELISA approach. Therefore, rats were pre-treated for one week with resveratrol plus quercetin prior to the induction of the disease by a toxic dose of APAP, and the histological and biochemical parameters were monitored and confirmed the beneficial effects of these agents (Figs. 1-4). Resveratrol plus quercetin markedly inhibit kidney injury and effectively inhibit the modulation of MDA, SOD, TNF$\alpha$, and IL-6 in APAP-induced acute nephrotoxicity in rats. Our data that point to the beneficial effects of resveratrol plus quercetin that ameliorate the deleterious effects of paracetamol are in agreement with the previously published studies that showed resveratrol protects against several types of renal injury induced by several methods such as diabetic nephropathy, drug-induced injury, and aldosterone-induced renal injury (Kitada \& Koya, 2013), and quercetin improved renal function and protected the kidney in a rat model of adenine-induced chronic kidney disease (Yang et al., 2018). However, conflicting data on the protective / treatment effects of resveratrol alone against APAP-induced acute liver injury 
in rats have been reported (Wojnarová et al., 2015; Elbe et al., 2018). A recently published work (Elbe et al.) reported a significant inhibition of liver iNOS immunostaining and hepatocyte ultrastructure damage by RES $(10 \mathrm{mg} / \mathrm{kg})$ given 20 minutes post APAP $(1 \mathrm{~g} / \mathrm{kg})$ injection in rats. Whereas, administrating triple-dose RES $(30 \mathrm{mg} / \mathrm{kg})$ at the same time with APAP $(1 \mathrm{~g} / \mathrm{kg})$ to rats caused a weak inhibition of biomarkers of liver injury, ALT and no effect on the ALT levels in cultured hepatocytes prepared from these animals (Wojnarová et al.). In addition, the same group (Wojnarová et al.) found no significant pathological changes in the liver tissue of the model group (APAP) stained with H\&E. Whereas, our H\&E images demonstrated a substantial kidney damage induced by APAP (Figs. 1C and 1D). Our treatment protocol (2 $\mathrm{g} / \mathrm{kg}$ APAP) versus their treatment protocol ( $1 \mathrm{~g} /$ $\mathrm{kg}$ APAP) could be the reason of such differences.

Collectively, our data support the conclusion that pretreatment with resveratrol plus quercetin can effectively protect against acute kidney injury and inhibits inflammatory and oxidative stress biomarkers in a rat model of APAP overdose-induced nephrotoxicity.

ACKNOWLEDGEMENTS: The authors would like to thank Dr. Mariam Al-Ani from Dental Care Partnership, Sutton Coldfield, Birmingham, UK for proofreading the manuscript.

HAIDARA, M.A.; AL-HASHEM, F.; EL KARIB, A. O.; ZAKI, M. S.; KAMAR, S. S.; EL-BIDAWY, M. H. \& AL-ANI, B. Inhibición de daño renal agudo inducido por paracetamol en ratas usando una combinación de resveratrol y quercetina. Int. J. Morphol., 37(4):1422-1428, 2019.

RESUMEN: La sobredosis de paracetamol (también llamado acetaminofen o APAP) causa un daño agudo en el hígado y los riñones, tanto en humanos como en modelos animales experimentales, a través de la inducción de la vía del estrés oxidativo. Intentamos determinar si los antioxidantes y los compuestos antiinflamatorios combinados, el resveratrol (RES) y la quercetina (QUR) pueden proteger contra la lesión renal inducida por una dosis tóxica de APAP en un modelo de rata de lesión renal aguda inducida por APAP. Las ratas recibieron una dosis única de APAP $(2 \mathrm{~g} / \mathrm{kg}$ ) antes de ser sacrificadas después de 24 horas o se trataron previamente durante 7 días con dosis combinadas de RES (30 $\mathrm{mg} / \mathrm{kg}$ ) y QUR (50 mg / kg), antes de ser tratadas, se administró una dosis única de APAP y luego fueron sacrificadas 24 horas después de la ingestión. Los tejidos renales recolectados se tiñeron con H-E y fueron observados a través de microscopía óptica. Las muestras de tejido se analizaron para (i) biomarcadores de estrés oxidativo y antioxidante, malondialdehído (MDA) y superóxido dismutasa (SOD); y (ii) biomarcadores de inflamación, factor de necrosis tumoral alfa (TNF- $\alpha$ ) e interleucina-6 (IL-6). Las imáge- nes teñidas con $\mathrm{H} \& \mathrm{E}$ mostraron que la sobredosis de APAP indujo daño renal agudo como lo demuestra la ampliación del espacio glomerular, la dilatación tubular, numerosos desechos celulares en los túbulos renales con degeneración epitelial tubular y la vacuolización, que se protegieron eficazmente con RES + QUR Se observó una protección parcial del espacio glomerular. Además, APAP modificó significativamente $(\mathrm{p}<0.05)$ los niveles tisulares de MDA, SOD, TNF- $\alpha$ e IL-6, que estaban protegidos por RES + QUR. Además, se observó una correlación positiva significativa ( $\mathrm{p}<0,0001)$ entre el espacio glomerular y el TNF- $\alpha$, $(\mathrm{r}=$ $0,8899)$, IL-6 $(r=0,8986)$ y MDA $(r=0,8552)$, mientras que la puntuación del espacio glomerular versus SOD mostró correlación negativa $(r=-0,7870)$. Concluimos que el resveratrol más quercetina protege sustancialmente contra la lesión renal aguda inducida por APAP en ratas, posiblemente a través del aumento de antioxidantes y la inhibición del estrés oxidativo y la inflamación.

PALABRAS CLAVE: Lesión renal aguda; Paracetamol; Resveratrol; Quercetina; Modelo de rata.

\section{REFERENCES}

Al-Ani, B. Resveratrol inhibits proteinase-activated receptor-2-induced release of soluble vascular endothelial growth factor receptor-1 from human endothelial cells. EXCLI J., 12:598-604, 2013.

Al-Hashem, F.; Al-Humayed; S.; Amin, S. N.; Kamar, S. S.; Mansy, S. S.; Hassan, S.; Abdel-Salam, L. O.; Ellatif, M. A.; Alfaifi, M.; Haidara, M. A.; et al. Metformin inhibits mTOR-HIF-1a axis and profibrogenic and inflammatory biomarkers in thioacetamide-induced hepatic tissue alterations. J. Cell Physiol., 234(6):9328-37, 2019.

Askari, H.; Seifi, B.; Kadkhodaee, M.; Sanadgol, N.; Elshiekh, M.; Ranjbaran, M. \& Ahghari, P. Protective effects of hydrogen sulfide on chronic kidney disease by reducing oxidative stress, inflammation and apoptosis. EXCLI J., 17:14-23, 2018.

Blazka, M. E.; Elwell, M. R.; Holladay, S. D.; Wilson, R. E. \& Luster, M. I. Histopathology of acetaminophen-induced liver changes: role of interleukin 1 alpha and tumor necrosis factor alpha. Toxicol. Pathol., 24(2):181-9, 1996.

Burda, S. \& Oleszek, W. Antioxidant and antiradical activities of flavonoids. J. Agric. Food Chem., 49(6):2774-9, 2001.

Cudmore, M. J.; Ramma, W.; Cai, M.; Fujisawa, T.; Ahmad, S.; Al-Ani, B. \& Ahmed, A. Resveratrol inhibits the release of soluble fms-like tyrosine kinase (sFlt-1) from human placenta. Am. J. Obstet. Gynecol., 206(3):253.e10-5, 2012.

Elbe, H.; Gul, M.; Cetin, A.; Taslidere, E.; Ozyalin, F.; Turkoz, Y. \& Otlu, A. Resveratrol reduces light and electron microscopic changes in acetaminophen-induced hepatotoxicity in rats: Role of iNOS expression. Ultrastruct. Pathol., 42(1):39-48, 2018.

Faghihzadeh, F.; Hekmatdoost, A. \& Adibi, P. Resveratrol and liver: A systematic review. J. Res. Med. Sci., 20(8):797-810, 2015.

Frankel, E. N.; Waterhouse, A. L. \& Kinsella, J. E. Inhibition of human LDL oxidation by resveratrol. Lancet, 341(8852):1103-4, 1993.

Hawton, K.; Simkin, S.; Deeks, J.; Cooper, J.; Johnston, A.; Waters, K.; Arundel, M.; Bernal, W.; Gunson, B.; Hudson, M.; et al. UK legislation on analgesic packs: before and after study of long term effect on poisonings. B. M. J., 329(7474):1076, 2004.

Henderson, C. J.; Wolf, C. R.; Kitteringham, N.; Powell, H.; Otto, D. \& Park, B. K. Increased resistance to acetaminophen hepatotoxicity in mice lacking glutathione S-transferase Pi. Proc. Natl. Acad. Sci. U. S. A., 97(23):12741-5, 2000. 
Hinson, J. A.; Reid, A. B.; McCullough, S. S. \& James, L. P. Acetaminopheninduced hepatotoxicity: role of metabolic activation, reactive oxygen/ nitrogen species, and mitochondrial permeability transition. Drug Metab. Rev., 36(3-4):805-22, 2004.

Hung, L. M.; Chen, J. K.; Huang, S. S.; Lee, R. S. \& Su, M. J. Cardioprotective effect of resveratrol, a natural antioxidant derived from grapes. Cardiovasc. Res., 47(3):549-55, 2000.

James, L. P.; Mayeux, P. R. \& Hinson, J. A. Acetaminophen-induced hepatotoxicity. Drug Metab. Dispos., 31(12):1499-506, 2003.

Karaali, H. F.; Fahmi, R. R. \& Borjac, J. M. Effect of Ocimum basilicum leaves extract on acetaminophen-induced nephrotoxicity in BALB/c mice. J. Complement. Integr. Med., 16(2), 2018. Doi: 10.1515/jcim2018-0111

Kitada, M. \& Koya, D. Renal protective effects of resveratrol. Oxid. Med. Cell. Longev., 2013:568093, 2013.

Larson, A. M.; Polson, J.; Fontana, R. J.; Davern, T. J.; Lalani, E.; Hynan, L. S.; Reisch, J. S.; Schiødt, F. V.; Ostapowicz, G.; Shakil, A. O.; et al. Acetaminophen-induced acute liver failure: results of a United States multicenter, prospective study. Hepatology, 42(6):1364-72, 2005.

McGill, M. R.; Sharpe, M. R.; Williams, C. D.; Taha, M.; Curry, S. C. \& Jaeschke, H. The mechanism underlying acetaminophen-induced hepatotoxicity in humans and mice involves mitochondrial damage and nuclear DNA fragmentation. J. Clin. Invest., 122(4):1574-83, 2012.

Ostapowicz, G.; Fontana, R. J.; Schiødt, F. V.; Larson, A.; Davern, T. J.; Han, S. H.; McCashland, T. M.; Shakil, A. O.; Hay, J. E.; Hynan, L.; et al. Results of a prospective study of acute liver failure at 17 tertiary care centers in the United States. Ann. Intern. Med., 137(12):947-54, 2002.

Ravarotto, V.; Simioni, F.; Pagnin, E.; Davis, P. A. \& Calò, L. A. Oxidative stress - chronic kidney disease - cardiovascular disease: A vicious circle. Life Sci., 210:125-31, 2018.

Rogerio, A. P.; Kanashiro, A.; Fontanari, C.; da Silva, E. V.; LucisanoValim, Y. M.; Soares, E. G. \& Faccioli, L. H. Anti-inflammatory activity of quercetin and isoquercitrin in experimental murine allergic asthma. Inflamm. Res., 56(10):402-8, 2007.

Wojnarová, L.; Kutinová Canová, N.; Farghali, H. \& Kucera, T. Sirtuin 1 modulation in rat model of acetaminophen-induced hepatotoxicity. Physiol. Res., 64 Suppl. 4:S477-87, 2015.

Yang, H.; Song, Y.; Liang, Y. N. \& Li, R. Quercetin treatment improves renal function and protects the kidney in a rat model of adenine-induced chronic kidney disease. Med. Sci. Monit., 24:4760-6, 2018.

Zhang, J.; Sheng, Y.; Shi, L.; Zheng, Z.; Chen, M.; Lu, B. \& Ji, L. Quercetin and baicalein suppress monocrotaline-induced hepatic sinusoidal obstruction syndrome in rats. Eur. J. Pharmacol., 795:160-8, 2017.
Corresponding author:

Professor Bahjat Al-Ani

Department of Physiology

College of Medicine

King Khalid University

Abha 61421

SAUDI ARABIA

Email: bahjat_alani@yahoo.com

Received: 21-03-2019

Accepted: 28-06-2019 